Session 3422

\title{
Faculty Development Workshops on the Road: What's Missing?
}

\author{
Katherine Sanders, Chris Carlson-Dakes, \\ John Mitchell, Pat Farrell \\ University of Wisconsin - Madison
}

\begin{abstract}
A common model for faculty development in higher education is what we refer to as the "visiting scholar" model. We have participated in this model for a number of years, and find it has some serious drawbacks, and is quite limited in its ability to help faculty reconsider and change what they do on a continuing basis. That is, unless a campus has an underlying structure to stimulate and support ongoing faculty growth, visiting scholars are unlikely to affect deep and lasting change in the way faculty think about learning and teaching. We describe our experiences as visiting scholars and in hiring visiting scholars for our own campus and compare our own faculty development program that provides an underlying structure for these ongoing discussions. We will then propose a model that would expand the visiting scholar model, so that innovations and organizational learning could more effectively move across and within institutions.
\end{abstract}

\section{Introduction}

It is important to our discussion to clarify a number of the concepts that we use, such as "visiting scholar," "workshop," and what we mean by creating a "successful" faculty development experience. To begin with, we view a visiting scholar as a person who is hired by an institution to come give a talk, lead a workshop, or in some other way communicate particular expertise or skills to a local audience. This visitor is typically chosen because of expertise in a specific area, and that area has already been defined by someone at the institution as of value and/or complementary to the direction the organization wishes to move. In sum, someone has determined that what that visitor has to offer is a valuable contribution to the local community. In the context of this paper, the person making this decision might be running a faculty development center, an administrator, or a faculty member who has a personal interest in a topic.

We consider workshops to be a learning environment that is rather short-term. That is, people would come together for a period ranging from two hours or one-half day to one or two days to learn together. The expected outcome is for the participants to apply what they learn at the end of the time period. Workshop environments, in our experience, might have people dropping in and out, perhaps coming and going to teach classes, work in their offices, answer email, or go to 
another meeting. The people in attendance are typically faculty and faculty development staff, sometimes graduate students, but very seldom are administrators such as department chairs, deans or provosts. Because of the relatively short time these people are together, workshop topics tend to focus on specific skills as opposed to theoretical or philosophical issues. Many times, the "hook" to encourage attendance is to assure faculty attendees that if they put in the hours (or days), they will leave with something tangible, a product of sorts, that can be used immediately. Those scholars who are most adept at creating and marketing those sorts of products are very popular and well paid visitors.

This brings us to the concept of what we mean by having a "successful" faculty development experience. For us, as visiting scholars giving one or two-day workshops, we would view "success" as helping faculty change the way they view the social system of learning and teaching and their roles within that system. We would view our visit as successful if the faculty created a venue for them to continue to learn and grow as learners and teachers, with the full support of the administration. That is, we would view a visit successful if we could be contributing to a sustainable conversation - a conversation that would be advancing a change of culture. Raising issues that are in effect, dead, a few weeks after our departure would not be a successful experience for us. Change by or in an individual may occur even in largely "unsuccessful" visits. We realize that hundreds of students can be affected by one faculty member's change, and we do not mean to minimize those individual changes. However, in many cases, the expense and effort involved in the visiting scholars model over time appears to be much greater than the payoff.

As people who hire visiting scholars occasionally, our view of a "successful" investment is one that engages our faculty in an ongoing discussion where they can critically examine how, when and why parts of the visitor's message might be useful for them. We typically hire visitors who have controversial or non-mainstream messages to infuse new interest or open alternative venues for faculty to explore. These visitors are invited at a time when a faculty discussion group as ready and eager for "outside" input to consider in their discussions.

\section{Visiting Scholar Model}

The visiting scholar model is a very logical and intuitive model for helping people learn from experts at other institutions. It is based on a number of assumptions, such as the assumption that there are people who know more about a given topic who are outside the local community than those who are inside that community, and/or the visitors would receive more "respect" or "expert status" because they are not part of the local community. From experience, we do know that sometimes novelty, or being outside a community, can lend credibility to a message. Many institutions have Schools of Education, but in teaching and learning theory, there are few engineering schools that take advantage of the wealth of expertise, experience, and resources these schools (frequently on their own campus) have to offer. The reasons for this are myriad, and some are political in nature, but it seems that part of the attraction of the visiting scholar model is that the scholar is by definition given "expert" status, where the "truth" she/he offers is colored more by her/his institutional credentials than by personal characteristics or local knowledge. 
One reason that the visiting scholars model may be attractive is because it requires lower maintenance than some of the alternatives. It relies on the selection and organization of visitors, with perhaps some attention to potential follow-up discussions after the visitor's departure, but it requires no permanent staff, permanent physical space, or long-term programmatic plan. If an institution wishes to get ideas introduced to its faculty without putting together resources, planning local activities or exploring local experts, it can easily look to the national media and conferences in higher education to find the names of scholars who would likely be available for workshops. Since these people are quite well known by major organizations, and have likely published in education literature, it is easy to assume that their message is unique; that it is based on information that only they or a small set of experts have access to. This assumption is closely related to other commonly held attitudes in engineering about where and in whom expertise resides. For example, there is the attitude that educational knowledge and practice from K-12 and adult education can not be directly applicable to higher education.

The visiting scholar model also relies on the assumption that most of the local audience has the same learning needs and desires and roughly the same availability. That is, since a workshop is scheduled for a given time with a defined agenda, it is necessary that the local audience be available to participate. If one misses the workshop, one might have a summary or materials to rely upon, or a video tape to review, but seldom would one have the chance to engage the speaker or other participants at another time. It is also necessary that the visitor make some assumptions about where the audience is in terms of its openness or readiness to engage the material.

Yet another assumption embedded in the visiting scholar model is that skills and the techniques of teaching are all that is necessary and sufficient to provide the nurturing and growth that faculty need throughout their careers as teachers, researchers, and administrators. For example, some institutions begin faculty development efforts by paying scholars to visit their campus and teach people skills that are immediately useful in their classrooms. A series of such visits might be labeled a "Faculty Development Program" in that they develop faculty skills, which are hopefully adopted and implemented for long periods of time. We question the claim that even very well-received workshops can be effective at changing long-term behavior and beliefs, and that faculty development can be wholly described by skill development. We will expand upon this assertion in the following section.

Finally, the visiting scholar model can be (and unfortunately, in our experience, many times is) initiated without much context. This means that visitors can be chosen to speak about topics that may or may not be related to each other, and by people who may not have similar or complementary beliefs about education. The schedule of visitors might be somewhat of a grabbag of ideas, from which workshop attendees are expected to choose what is of interest to them. Although we believe that choice and browsing educational techniques is a valuable contribution, this approach does not help faculty systematically or deeply reflect on, develop, or advance their own belief systems about learning and teaching. In general, there is no continuity between discussions, and no common language, discourse, or critique for a community of faculty to use to evaluate the information the visitors share. Thus there is a very limited synthesis and integration of the ideas of disparate visitors, perhaps leaving a local community with the impression that the 
ideas they are hearing are not connected in any meaningful way, nor leading to any foundational conclusions. In some cases, those inviting the visiting scholar may view him or her as a potential catalyst that will somehow motivate listeners to begin the process of reflection and discussion we describe as so important to deep and lasting change in faculty attitudes and actions. Our experience is that a single visiting scholar event will not affect that kind of action without extensive supporting activity before and after the event.

\section{Creating a Collaborative Learning Environment Model}

The model for faculty development we will contrast to that of the visiting scholar model is a program called Creating a Collaborative Learning Environment (CCLE). CCLE is designed to create a safe space for faculty to reflect on their belief systems about learning and teaching and to help each other take action to change their own jobs as learners and teachers. In CCLE, faculty from across the campus volunteer to participate in a minimum of a year-long intensive program where they collaborate to learn from each other, learn about learning, question their assumptions about themselves, their students, and the institution, and begin to address issues of reform in higher education.

Even though CCLE was named by faculty participants to describe their experiences as learners together, the name creates some confusion. CCLE is commonly thought to be either a program to teach collaborative learning teaching techniques, or a type of teaching circle discussion group. While collaborations among students may be one possible outcome of faculty learning, more fundamentally, CCLE strives to create collaborations among faculty as they themselves experience learning in a new and challenging environment. Its first year of activities are fundamentally different from a teaching circle in that the activities center on learning and are structured in a common curriculum that meets weekly over an academic year. CCLE also explicates and develops understandings of the processes of collaboration and consensus building as part of the curriculum. The theoretical approach and applied structure of CCLE evolved out of a PhD dissertation (Sanders) ${ }^{1}$ and are based on theories of job enrichment ${ }^{2}$, job characteristics theory ${ }^{3}$, action research ${ }^{4}$, and participatory management ${ }^{5}$.

CCLE is a grass-roots, voluntary professional development process that centers on the construction of knowledge in faculty teams. It is not a program instituted in a hierarchical manner. As a result, we are told by participants, is the development of a uniquely safe environment in which ideas are shared more openly than in other settings faculty typically encounter. The faculty participate in a collaborative process designed to help them develop collaboration skills, an understanding of the learning process, and an appreciation for the need for change in teaching content, approach, and curriculum. CCLE also provides a support structure through which changes can be implemented and innovative ideas supported on a continuous basis ${ }^{6}$.

The program has two stages of participation designed to provide a support structure for group learning, exposure to general educational information, and preparation for practitioner action in the classroom (see Figure 1). Stage 1 is a year-long commitment to meet weekly for 1.5 hours as a team of six to eight faculty and a facilitator. Early activities and discussions revolve around 
introductory educational literature, different learning styles, and issues of diversity. These discussions are followed by activities designed to draw upon the participants own experiences as learners and to help the group arrive at a consensus diagram representing their concept of the learning process.

If they choose, faculty who finish Stage 1 can continue their work in Stage 2 in which they again meet weekly and work with a facilitated team. They have three options for Stage 2 teams. One is a "Classroom Experimentation" team designed to provide a framework for planned implementation of classroom innovations, mentored and observed by other team members. The second type of team is an "Advanced Learning Team" where the faculty collaborate on an indepth study of a topic of the group's choice (e.g. instructional technologies, gender issues in teaching, teaching large classes, developmental assessment, student motivation, critical thinking). The third type is a "Seminar Series Team" in which the CCLE meetings coincide with a monthly campus wide Teaching and Learning Colloquium Series. The CCLE meetings between the monthly colloquia presentations focus on topics raised during the colloquia. The topics and participants of Stage 2 teams change each semester, so faculty often continue their commitment to their development by staying connected with CCLE for several semesters. In fact, over $50 \%$ of those eligible to participate in advanced stages of CCLE have chosen to do so.

\section{Results}

Our research indicates that CCLE has been very successful in developing and maintaining positive change for faculty participants with regard to their teaching ${ }^{7}$. CCLE teams have provided a spark for many faculty and departments to begin discussions about alternative approaches to teaching as well as to reconceptualize their overall work. We have seen significant changes for many at the individual level. Faculty have integrated the concepts into their normal work day with close colleagues who can collectively instigate and support each other in change. This is in contrast to other models where discussions about teaching are special events, or additional sessions or workshops presented by outside visitors. The message may be that for these activities, ways of addressing these issues must come from outside experts and are beyond the scope of normal daily faculty tasks.

As individual faculty develop, form community and diffuse their ideas outward to their colleagues, we are beginning to see changes in the complexion of faculty work on campus as the organization changes through new teaching and research collaborations, committee work, and departmental management approaches. Additionally, our research has found that a new language is being used as faculty engage in conversations with other CCLE faculty who have also taken part in this type of intense collaborative professional development process. This results in faculty interacting with each other in new ways and taking new approaches to their work. We agree with John Bean's statement, "If faculty members can talk of their work in a new way, they can work in a new way." 8 These new approaches to work facilitate deep, sustained, and what we consider positive movement in the direction of reform of higher education.

The CCLE program has been in existence for seven years. During that time, about 170 faculty 
have participated in the program. Each semester there are about 25 new faculty who volunteer to start the program (Stage 1), and about 25 faculty who continue their learning in advanced sessions (Stage 2). The program is funded by two full-time staff who work out of the Office of the Provost. Both the continued advocacy and enthusiasm of CCLE participants and the financial support from the Provost have contributed to the success of the program.

In addition to our local involvement with CCLE, we have served as "visiting scholars" and presented our work at numerous local and national professional conferences. We have also been invited as speakers to seven institutions to conduct workshops to disseminate the model of CCLE, and have hosted a two-day faculty development workshop for NSF Foundation Coalition institutions. A summary of these presentations and workshops is given in Table 1.

It has been difficult to determine the lasting impact of these activities on the participating institutions, especially since in most cases there has been limited availability of resources and personnel at the various campuses to move from enthusiastic interest toward adaptation and implementation of a similar model. There have been, however, isolated cases where we have engaged in ongoing conversations with other institutions to move in the direction of adapting a CCLE-like model elsewhere. Since this kind of faculty development program is new to most campuses we visit, we gauge the impact of the visit to some extent on the quantity and quality of follow-up contacts with the faculty on the campus we have visited.

For example, connections were made at the NSF Cross Coalition Conference on Faculty Development which attracted an audience for a faculty development conference we hosted at UW-Madison (funded by the NSF Foundation Coalition). From this conference, we have maintained close communication with one of the four attending institutions as they work to redefine the direction of their teaching and learning center on campus. Part of this ongoing relationship consisted of a two-day visit to their campus to discuss our approach and model with their faculty, administration, (Provost, Associate Vice Chancellor) in the context of their established teaching center. A combination of appropriate timing, administrative and faculty attendance and support, and adequate dedicated support staff have helped this relationship continue to grow. They have the benefit of having support and resources from faculty, support staff, and upper level administration. They are also in a transition period and very open to taking new directions for faculty development on their campus.

We also participated in the NSF Visiting Scholars program that provided a venue for ongoing conversations to occur and relationships to develop. CCLE staff and faculty visited two campuses twice in the span of three months. These repeat visits were intended to introduce the philosophy and model of CCLE, provide a framework with which to progress through early stages of adaptation, and create a space and timeline to create movement between the visits. Once the formalized visiting scholars program was over, however, the close communication and impetus for movement seemed to taper off. There have been sporadic follow-up inquiries from individual faculty members, however the collective group did not seem to coalesce, and it is not clear that a common direction was found.

Even at other UW System campuses, follow up and ongoing conversations have been difficult to maintain. Our workshops and conference presentations tend to generate interest and enthusiasm 
immediately following the session, but without a group of supportive colleagues to advance the discussions, this model of faculty development cannot grow and thrive. Thus, to date CCLE has not been adapted by another institution. The University of New Brunswick at St. John has used CCLE resources to create a teaching discussion group; however, a teaching circle does not set out to accomplish the goals and collaborative activities of CCLE. Because St. John does not have a faculty development staff person to support such a program, it is not possible at this time for them to implement a CCLE-like program.

As summarized in Table 1, for the 13 cases listed, there have been follow-up requests from nine visits. Individual faculty from six institutions have phoned to discuss various aspects of program initiation, administration, teaching, and learning. We are planning to visit one of the schools that participated with us in the Foundation Coalition. One presentation resulted in faculty participation in a workshop on our campus, and it from that workshop that the only progress in establishing a similar program has resulted.

\section{A Proposed Model}

We do believe there is a place for the visiting scholar. However, we also believe there needs to be growth between visits, where faculty locally make meaning of what they learned, experiment with the information, and adapt their practice to their new understandings. Essentially, we believe that the emphasis must be changed so that the guest "expert" is not the one who is responsible to decide what should be done and how to do it. Rather, the focus and resources should be placed on a continuing conversation within the local community, complemented by the input from a visitor to provide new perspectives and new ideas. The visitor can perform a valuable function by introducing controversial and challenging ideas in addition to specific skills or expertise. We believe that no matter how inspirational or educational a visitor's one- or twoday workshop is, unless the participants continue to grow, learn and construct a personal meaning of the subject in their own context and in their own community, they are unlikely to make any deep or lasting change in their practices or beliefs.

We find that for the most part, the missing piece from the visiting scholar model is context, which is the common language and shared understandings a local community uses to interpret, position, and make use of information and perspectives a visitor would share. In that light, we propose that faculty development conversations must be grounded in a local community before substantive changes that are stimulated by visitors can take place. The visitors can raise issues, but each local community must have a pool of potential leaders who can communicate with each other to move the organization forward. The message of a very articulate, competent "expert" will likely fall on deaf ears if the audience is not adequately prepared to listen, participate, interpret, and make meaning of the content. These audience activities, particularly meaningmaking, may take some time to develop, and are not likely to happen in the time frame of a 1 or 2 day workshop. Without this local communication to develop a common focus of interest, the "expert" may be off the mark and concentrate on a topic or issue that is not particularly pertinent to the local community at that particular time. If that communication and collaborative base are missing, the resulting innovations, skills or beliefs are less likely to take root and grow. 
We do feel visiting scholars are an important complement to an institution's faculty development efforts, and we hire two to three people each year for special events with our faculty. However, over the last seven years we have found that our resources are best spent by investing into the day-to-day activities of our faculty, providing them with a structure for learning in community with each other. This means that our purposes for hiring a visiting scholar have shifted. We do not put a visitor at the center of a program, as the major theme or content for faculty to learn about. Instead, we invite people who complement what the faculty are already wondering about, studying, exploring, as an additional resource to help them reach their own goals.

We have also found that having an ongoing relationship with a visiting scholar is very valuable. We have formed relationships with colleagues from other institutions who visit a first time to add a dimension to what we are already studying, and then revisit us year after year, to continue that conversation. For example, we have had had an ongoing relationship with Professor Tim Riordan from nearby Alverno College since 1994. As he continues to work with us over time (visiting approximately two or three times each year, to work directly with CCLE staff, or give a talk to faculty), we find that our questions become more specific. We find that we can make much more use of his recognized expertise by having an ongoing conversation with him, and we feel sometimes as if he is a real consultant to the University. In sum, our relationship has developed far beyond that of a "visitor." We feel we have a friend and advocate outside the institution that we can consult for a number of projects. Since he knows our audience, intentions, and values, he can make suggestions and be involved in more of the creative longterm approaches we develop.

Given our belief in the long-term social construction of learning and organizational change, the model we propose is one of familiarity and consistency. We believe that the deep learning required in order for faculty to re-think what they're doing, why they're doing it, and how they might do it differently (in effect, redesigning their jobs) requires sustained inquiry and reflection. In CCLE we place an emphasis on meeting weekly to discuss ideas, interpret meaning, and create common understandings. The role of the visiting scholar in our model is to elaborate or expand philosophical ideas our groups are already exploring (e.g., diversity, privilege, learning theory) or to bring these philosophical frameworks down to a skills level (e.g., critical thinking, collaborative learning, inclusivity). Additionally, we hire people who we believe will be inspirational speakers who can share a non-traditional voice with our faculty in order to bring alive what they have already been reading and discussing.

When we find ourselves in the role of visiting scholar in the future, especially given the nature of what we are trying to accomplish with faculty, we know that long-term connections with institutions are essential to success. We will need to work closely with the local faculty development professionals in order to understand the local culture and needs. If an institution currently does not have a structured system for creating ongoing deep conversations about education, we will need to help the faculty development staff create those forums. Our visits will not be good investments unless they are proceeded by and followed with local action. We need to visit within a context on ongoing systematic inquiry into the philosophy and practice of education. To do this, we will propose that we establish regular visits in person and by telephone/email so that as faculty development professionals we can begin to collaborate as colleagues. Our relationships with the local faculty need to be ongoing as well, with some 
formal, structured venues for communication when we are not on campus, and ways for them to communicate to us and their own faculty development staff what they are wondering about and moving towards.

Additional links between faculty development professionals might take place in professional organizations such as the Professional and Organizational Developers Network (POD), the American Association of Higher Education (AAHE), or the American Society of Engineering Education (ASEE). If strong networks of consultation and mutual education were in place in these professional societies, links between institutions could be deeper and more long lasting. And the importance and potential structures for affecting organizational learning through local programs could be shared more easily.

\section{Conclusions}

At our own institution, as the people who would hire visiting scholars to enrich and expand our faculty development opportunities, we believe we have found an effective balance between invited guests and internal work. We find that our work within CCLE and a number of other community venues (e.g., Teaching Academy, Center for Biology Education, Engineering Learning Center) helps us create a context for appreciating the ideas of visiting scholars. We have created ongoing partnerships and consultative relationships with scholars from other institutions that have helped us create new programs and advance our own initiatives. We find this is money well spent. More generally, we find visitors most effective when the purpose of the visit has been clearly described to visitor and audience in advance, and the activities and outcomes of the visit are consistent with the stated purposes.

However, as visiting scholars ourselves, we struggle with finding a way to connect to the institutions that hire us in ways that help their faculty move forward over time. We find that the nature of the work we do, in particular, does not translate easily into a workshop format, perhaps because it is not skills-based. In effect, our role at UW-Madison is to create and nurture a community of learners (faculty), and we find that very challenging to do from a distance, particularly at institutions when no other faculty development staff or infrastructure currently exists. We think the key to these efforts is long term relationships between faculty development staff so that visiting scholars can connect over time with faculty from local communities, to help them move forward toward their own local agendas, acting as resources when appropriate, and introducing controversial ideas and voices that are commonly not heard. We believe that this role for the visiting scholar will be effective and worthwhile in the long term.

Bibliography

1. Sanders, K. J. (1993). The Effects of a Participatory Process to Improve College Teaching. Unpublished doctoral dissertation, University of Wisconsin-Madison.

2. Herzberg, F. (1974). The wise old Turk. Harvard Business Review, September-October, 70-80.

3. Hackman, J. R., Oldham, G. R., Janson, R., and Purdy, K. (1975). A new strategy for job enrichment. California Management Review, 17, (4), 57-71. 
4. Lewin, K. (1947). Frontiers in group dynamics: channels of group life, social planning and action research. Human Relations, 1 (2), 143-153.

5. Lawler, E.E. (1986). High Involvement Management. San Francisco: Jossey-Bass.

6. Sanders, K., Carlson-Dakes, C., Dettinger, K., Hajnal, C., Laedtke, M., and Squire, L. (1997). A new starting point for faculty development in higher education: Creating a Collaborative Learning Environment. In D. DeZure (Ed.), To Improve the Academy, 16. 117-150. Stillwater, OK: New Forums Press.

7. Sanders, K., Dettinger, K., Hajnal, C., and Squire, L. (1995). Creating a collaborative learning environment: Pilot program results. Unpublished report, University of Wisconsin-Madison.

8. Bean, J. B. (1998). Alternative models of professional roles: New languages to reimagine faculty work. The Journal of Higher Education, 69, No. 5, September/October, 496-512.

\section{KATHERINE SANDERS}

Katherine Sanders is the Director of a faculty development center, "Creating a Collaborative Academic Environment," (CCAE) housed in the Provost's Office, and is part of the Wisconsin Center for Education Research. She received her B.S., M.S., and Ph.D. in Industrial Engineering from the UW-Madison, specializing in Human Factors Engineering and Socio-Technical Systems Engineering.

\section{CHRIS CARLSON-DAKES}

Chris Carlson-Dakes is the Associate Director of a faculty development center, "Creating a Collaborative Academic Environment," (CCAE) at the University of Wisconsin-Madison. He received his B.S. and M.S. in Mechanical Engineering at Carnegie Mellon University and the Pennsylvania State University, respectively, and his Ph.D. in Industrial Engineering from the UW-Madison in Human Factors and Socio-Technical Systems Engineering.

\section{JOHN MITCHELL}

John Mitchell is the Kaiser Chair Professor in Mechanical Engineering at the University of Wisconsin. He received his BS, MS, and Ph.D. degrees from Stanford University. Currently, he is the coordinator on the University of Wisconsin campus of the NSF-sponsored Foundation Coalition project.

\section{PAT FARRELL}

Patrick Farrell is a Professor of Mechanical Engineering at the University of Wisconsin-Madison. He received his BS from the University of Michigan, MS from the University of California at Berkeley, and Ph.D. from the University of Michigan. 
TABLE 1

CCLE in the Visiting Scholar Model

\begin{tabular}{|c|c|c|c|c|c|}
\hline Date & Event & Format/Title & Location & Audience & Outcome/Follow-up \\
\hline $\begin{array}{l}\text { Sept, } \\
1999\end{array}$ & Invited Speaker & One-day workshop & $\begin{array}{l}\text { University of New } \\
\text { Brunswick }\end{array}$ & $\begin{array}{l}\text { Cross campus Teaching } \\
\text { Excellence Committee }\end{array}$ & $\begin{array}{l}\text { Continued discussions } \\
\text { with faculty }\end{array}$ \\
\hline $\begin{array}{l}\text { Aug, } \\
1999\end{array}$ & $\begin{array}{l}\text { NSF Foundation } \\
\text { Coalition Summer } \\
\text { Curriculum Conference }\end{array}$ & $\begin{array}{l}\text { Two-hour session: } \\
\text { Organizational Learning and } \\
\text { Change }\end{array}$ & $\begin{array}{l}\text { University of } \\
\text { Wisconsin-Madison, }\end{array}$ & $\begin{array}{l}\text { Faulty from NSF } \\
\text { Foundation Coalition } \\
\text { Schools }\end{array}$ & $\begin{array}{l}\text { Potential visit to one } \\
\text { school }\end{array}$ \\
\hline $\begin{array}{l}\text { May, } \\
1999\end{array}$ & $\begin{array}{l}\text { Workshop on Faculty } \\
\text { Development for NSF } \\
\text { Foundation Coalition } \\
\text { Schools }\end{array}$ & $\begin{array}{l}\text { Two-day workshop on the } \\
\text { philosophy, background, and } \\
\text { implementation at their } \\
\text { institution }\end{array}$ & $\begin{array}{l}\text { University of } \\
\text { Wisconsin-Madison, }\end{array}$ & $\begin{array}{l}\text { Faculty and faculty } \\
\text { development } \\
\text { representatives from } \\
\text { four institutions }\end{array}$ & $\begin{array}{l}\text { Visit to one school to } \\
\text { help establish program } \\
\text { Continued discussions } \\
\text { with one school }\end{array}$ \\
\hline $\begin{array}{l}\text { Apr, } \\
1999\end{array}$ & $\begin{array}{l}\text { NSF Cross Coalition } \\
\text { Conference on Faculty } \\
\text { Development }\end{array}$ & $\begin{array}{l}\text { Session: Creating a } \\
\text { Collaborative Learning } \\
\text { Environment }\end{array}$ & $\begin{array}{l}\text { North Carolina State } \\
\text { University }\end{array}$ & $\begin{array}{l}\text { Faculty and faculty } \\
\text { development } \\
\text { representatives from } 11 \\
\text { institutions }\end{array}$ & $\begin{array}{l}\text { Generated faculty who } \\
\text { came to May workshop }\end{array}$ \\
\hline $\begin{array}{l}\text { Feb } \\
\text { Apr, } \\
1999\end{array}$ & $\begin{array}{l}\text { NSF/ASEE Visiting } \\
\text { Scholars Program }\end{array}$ & $\begin{array}{l}\text { Two, 2-day workshops to } \\
\text { discuss the philosophy, } \\
\text { background, and } \\
\text { implementation of CCLE }\end{array}$ & $\begin{array}{l}\text { State University of } \\
\text { New York at Buffalo }\end{array}$ & $\begin{array}{l}\text { Engineering faculty } \\
\text { and administration }\end{array}$ & $\begin{array}{l}\text { Individual phone calls } \\
\text { from faculty }\end{array}$ \\
\hline $\begin{array}{l}\text { Mar- } \\
\text { May, } \\
1998\end{array}$ & $\begin{array}{l}\text { NSF/ASEE Visiting } \\
\text { Scholars Program }\end{array}$ & $\begin{array}{l}\text { Two, 2-day workshops to } \\
\text { discuss the philosophy, } \\
\text { background, and } \\
\text { implementation of CCLE }\end{array}$ & University of Virginia & $\begin{array}{l}\text { Engineering faculty } \\
\text { and administration }\end{array}$ & $\begin{array}{l}\text { Individual phone calls } \\
\text { from faculty }\end{array}$ \\
\hline $\begin{array}{l}\text { Apr, } \\
1997\end{array}$ & $\begin{array}{l}\text { University of Wisconsin } \\
\text { System Conference }\end{array}$ & $\begin{array}{l}\text { Workshop: Creating a } \\
\text { Collaborative Learning } \\
\text { Environment for Faculty }\end{array}$ & Madison, WI & $\begin{array}{l}\text { Faculty and } \\
\text { administrators from the } \\
\text { UW System Schools }\end{array}$ & \\
\hline
\end{tabular}




\begin{tabular}{|l|l|l|l|l|l|}
\hline $\begin{array}{l}\text { Oct, } \\
1996\end{array}$ & $\begin{array}{l}\text { Higher Education } \\
\text { Annual Conference }\end{array}$ & $\begin{array}{l}\text { Seminar: Faculty Teamwork } \\
\text { at UW-Madison }\end{array}$ & Salt Lake City, UT & $\begin{array}{l}\text { Faculty development } \\
\text { staff and faculty from } \\
\text { universities }\end{array}$ & $\begin{array}{l}\text { Individual phone calls } \\
\text { from faculty }\end{array}$ \\
\hline $\begin{array}{l}\text { Jan, } 1996 \\
\text { Faculty Roles and } \\
\text { Rewards }\end{array}$ & $\begin{array}{l}\text { Seminar: Creating a } \\
\text { Collaborative Learning } \\
\text { Environment }\end{array}$ & $\begin{array}{l}\text { Atlanta, GA } \\
\text { administrators from } \\
\text { across the country }\end{array}$ \\
\hline $\begin{array}{l}\text { Nov, } \\
1995\end{array}$ & $\begin{array}{l}\text { Lilly Conference on } \\
\text { College Teaching }\end{array}$ & $\begin{array}{l}\text { Seminar: A Process for } \\
\text { Pedagogical and Curricular } \\
\text { Change at UW-Madison }\end{array}$ & $\begin{array}{l}\text { Miami University, } \\
\text { Oxford, OH }\end{array}$ & $\begin{array}{l}\text { Faculty from across the } \\
\text { country }\end{array}$ \\
\hline $\begin{array}{l}\text { Aug, } \\
1995\end{array}$ & $\begin{array}{l}\text { UW-Platteville: Women } \\
\text { and Science Program }\end{array}$ & $\begin{array}{l}\text { Workshop: Connected } \\
\text { Knowing and Learning in } \\
\text { Engineering Education }\end{array}$ & $\begin{array}{l}\text { University of } \\
\text { Wisconsin-Platteville }\end{array}$ & $\begin{array}{l}\text { Faculty and } \\
\text { administrators }\end{array}$ \\
\hline $\begin{array}{l}\text { Apr, } \\
1995\end{array}$ & $\begin{array}{l}\text { Upper Midwest Faculty } \\
\text { Forum }\end{array}$ & $\begin{array}{l}\text { Seminar: A Faculty } \\
\text { Development Program at } \\
\text { UW-Madison } \\
\text { Workshop }\end{array}$ & Houghton, MI & $\begin{array}{l}\text { Faculty and } \\
\text { administrators from the } \\
\text { region } \\
\text { from faculty }\end{array}$ & $\begin{array}{l}\text { Individual phone calls } \\
\text { from faculty }\end{array}$ \\
\hline $\begin{array}{l}\text { Jan, } \\
1995\end{array}$ & $\begin{array}{l}\text { UW-Stout Professional } \\
\text { Development Program }\end{array}$ & $\begin{array}{l}\text { Workshop: Introducing } \\
\text { Change in the Classroom }\end{array}$ & Menomonie, WI & $\begin{array}{l}\text { Faculty and } \\
\text { administrators from } \\
\text { UW-Stout }\end{array}$ \\
\hline
\end{tabular}




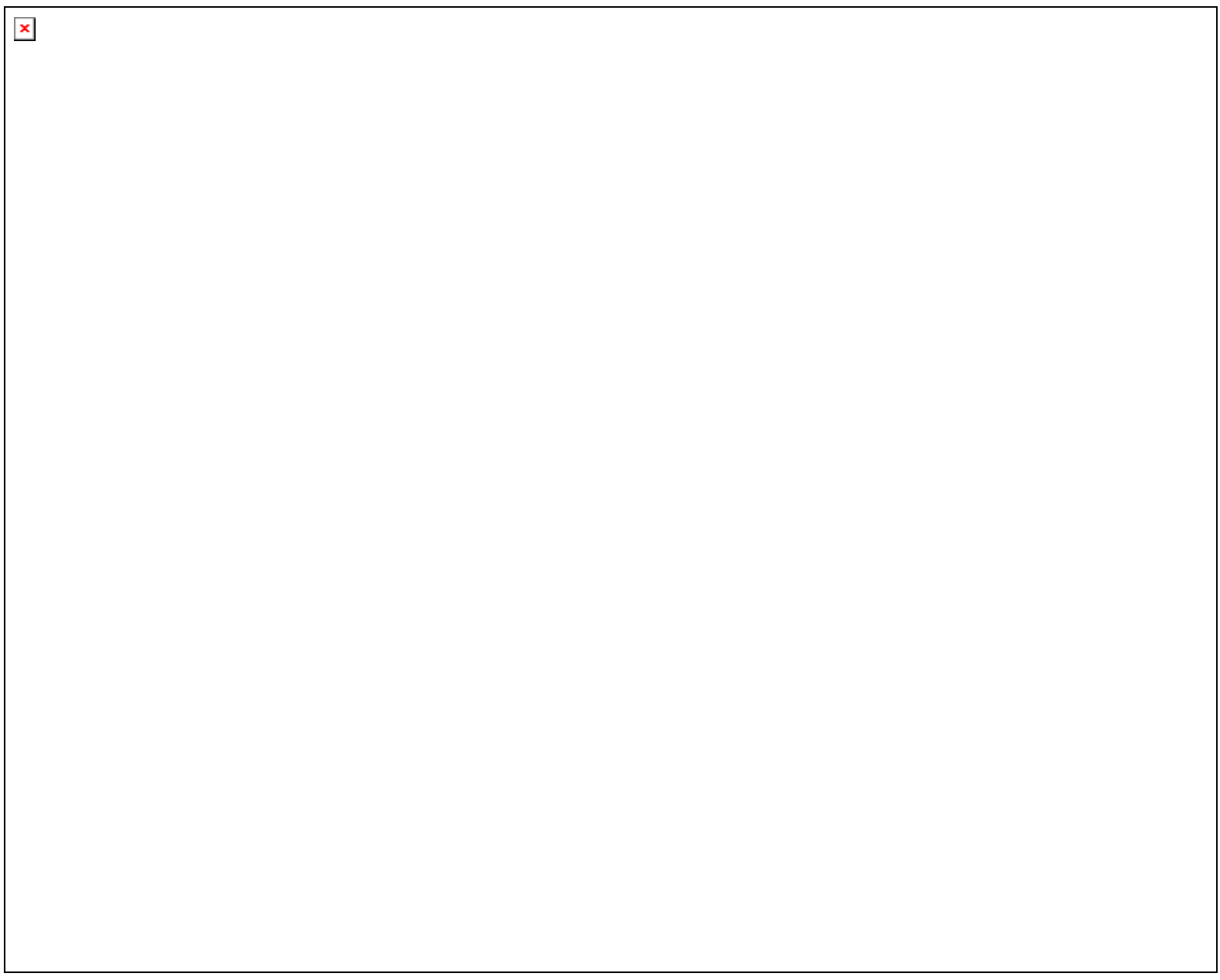

